\title{
The role of plants containing secondary compounds in sustainable deer farming - a review
}

\author{
S. O. HOSKIN, T. N. BARRY and P. R. WILSON \\ College of Sciences, Massey University, PN 452, Private Bag 11222, Palmerston North
}

S.O.Hoskin@massey.ac.nz

\begin{abstract}
The productivity and health of farmed deer is improved by substituting perennial ryegrass-based pasture with forages containing condensed tannins (CT) and/or sesquiterpene lactones. Benefits have included improved lactation, growth, trace element status, resilience to internal parasites and reductions in parasite larval development. Forages evaluated for deer include the forage legumes sulla and birdsfoot trefoil, which contain CT, and the herb chicory, which contains both CT and sesquiterpene lactones. Autumn grazing of weaner deer on chicory has shown growth can be increased whilst anthelmintic requirement reduced compared to grazing of perennial ryegrass/ white clover pasture. The importance of secondary compounds relative to other nutritive characteristics of alternative forage species, such as low fibre and highly digestible carbohydrate concentrations, have not been fully characterised, but they are likely to contribute to improved deer health. Unlike sheep and cattle, deer produce salivary proteins that bind CT, allowing them to consume plants containing higher $\mathrm{CT}$ concentrations than sheep and cattle. The effect of CT upon the digestion and absorption of protein, which has been determined for other domestic ruminants, needs to be measured in deer fed forage diets, to establish if beneficial effects exist. In vitro work has shown direct inhibitory effects of CT and sesquiterpene lactones extracted from forages on deer internal parasite larvae. The faeces, rumen and abomasal fluid of deer grazing chicory also contained substances reducing the viability of parasite larvae. Alternative plant species such as chicory, birdsf oot trefoil and forage willows containing secondary compounds will play an important role in low chemical sustainable deer farming.
\end{abstract}

Keywords: anthelmintic, Cichorium intybus, condensed tannins, forage, Hedysarum coronarium, internal parasites, protein, red deer

\section{Introduction}

The role of forages for deer production other than perennial ryegrass based pastures, many of which contain secondary plant compounds, has been the subject of two recent reviews by the authors (Barry et al. 2002; Wilson et al. 2002).

It is important for economic viability and market access that deer farmers continually improve both the level of production and the quality of products produced, with minimal chemical or drug input. A key aspect of sustainability is the relationship between animal health, welfare, production and product quality. In particular, widespread control of internal parasites using synthetic chemicals may be unsustainable in the long term, due to the increasing risk of anthelmintic resistance and the risk or perception of chemical residues in deer products. There is a growing consumer awareness of, and demand for, low-chemical input or 'naturally produced' deer products (Loza 2001). The focus on natural, rather than manufactured dietary supplements to provide essential trace elements and vitamins for farmed animals is increasing.

There is also a growing understanding of "the complexity offood resources and heterogeneity of natural environments" (Hanley 1997) from which our farmed deer species originated, both overseas and from within the wilds of New Zealand (NZ). This contrasts with the simple, homogenous ryegrass/ white clover pasturebased farming system. Deer farming in NZ is based largely on conventional pastoral sheep and beef production systems utilising perennial ryegrass (Lolium perenne)/ white clover (Trifolium repens) (PRG/WC) pastures. Although deer farmed in this system outperform feral deer (Moore et al. 1988), the mismatch between pasture growth patterns and deer feed demands and seasonal changes in pasture quality spurred research into alternative forage species, originally for venison production (Barry \& Wilson 1994). These studies have led to increasing awareness of, and slowly, research into, their influence on deer health, welfare and production, and potentially, environmental enrichment.

Chicory (Cichorium intybus) appears to be the forage species most suitable for deer production on a range of soils types across NZ given its relative persistence, ease of establishment and high deer feeding value (Kusmartono 1996). Birdsfoot trefoil (Lotus corniculatus) has shown potential for use as a pure species forage crop in drier, east-coast regions with freedraining soils (T.N. Barry pers. comm.) and narrowleaved plantain (Plantago lanceolata) has potential as a means of introducing a persistent CT-containing species as part of permanent pasture (Moorhead et al. 2002). Sainfoin (Onobrychus viciifolia), sulla (Hedysarum coronarium) and lotus major (Lotus pedunculatus) have limited potential for use in deer grazing systems due to agronomic limitations such as poor persistence 
(P.D. Kemp pers. comm.). Willow species (Salix spp.) are likely to be successful forage trees due to ease of planting poles and selection of cultivars for high yield and persistence, however the potential for use of native species as forage trees for deer should not be overlooked.

This paper reviews current and potential roles of plants containing secondary compounds in sustainable deer production systems. In particular, it reviews legumes containing condensed tannins (CT) and herbs containing sesquiterpene lactones that have been evaluated, or have the potential to be used, for in-situ forage grazing or supplementary browse feeding of farmed deer in NZ. The focus will be on current research and areas needing further research. Since most research conducted in this area involved red deer (Cervus elaphus), this review refers to red deer unless specified otherwise.

\section{Nutritional role of secondary plant compounds}

Plant secondary compounds or their metabolites, sometimes referred to as allelochemicals, are prevalent in the plant kingdom. They have effects on ruminants ranging from improved nutrition and health to interference with feed intake, digestion or metabolism of energy or nutrients and acute toxicity and death (Rosenthal \& Janzen 1979). Secondary compounds are produced as natural defence mechanisms against pathogenic micro organisms, insects and grazing by herbivores (Swain 1979). The group of secondary compounds best understood for deer is the phenolics, particularly CT (proanthocyanidins) in NZ. Addition- ally, kno wledge about sesquiterpene lactones present in forage chicory is emerging. Many other secondary compounds isolated from forage and browse species are frequently detrimental to ruminant health and production and will not be discussed.

The concentration of the major known secondary compounds in temperate forages suitable for deer and NZ growing conditions are shown in Table 1. Some trees, shrubs and forage legumes such as sulla and lotus major contain concentrations of $\mathrm{CT}$ that are considered too high or only marginally acceptable for sheep and cattle. Perennial ryegrass (Lolium perenne), white clover (Trifolium repens), red clover (Trifolium pratense) and lucerne (Medicago sativa) contain only traces of CT that are too low to have a nutritional benefit.

Condensed tannins, in contrast to most other phenolics, are beneficial to ruminant animal production at low to medium concentrations, especially in NZ where pastures have high soluble protein concentrations. Condensed tannins bind strongly to protein in a pH-dependant manner (Asquith \& Butler 1986). Condensed tannins are not absorbed from the digestive tract (Terrill et al. 1994). Medium CT concentrations in birdsfoot trefoil reduce rumen degradability of protein and increase amino acid absorption from the small intestine (Bermingham et al. 2001; Waghorn et al. 1994). In field experiments this increased reproductive rate (Min et al. 1999, 2001), wool growth, milk secretion and liveweight gain of sheep (Wang et al. 1996a,b). However, CT chemical structure and molecular mass, which vary between plant species,

Table 1 The concentration of secondary compounds ( $/ \mathrm{kg} \mathrm{DM}$ ) in forages grown in New Zealand (adapted from Barry et al. 2002 and unpublished).

\begin{tabular}{|c|c|c|}
\hline Plant & $\begin{array}{c}\text { Total condensed } \\
\text { tannins }\end{array}$ & $\begin{array}{l}\text { Other major secondary } \\
\text { compounds }\end{array}$ \\
\hline $\begin{array}{l}\text { Grasses } \\
\text { Perennial ryegrass* (Lolium perenne) } \\
\text { Annual ryegrass* (Lolium multiflorum) } \\
\text { Yorkshire fog (Holcus lanatus) }\end{array}$ & $\begin{array}{l}\text { Trace } \\
3-4 \\
4-5\end{array}$ & Endophyte alkaloids \\
\hline $\begin{array}{l}\text { Legumes } \\
\text { Sulla* (Hedysarum coronarium) } \\
\text { Birdsfoot trefoil* (Lotus corniculatus) } \\
\text { Lotus major (Lotus pedunculatus) } \\
\text { Lucerne* (Medicago sativa) } \\
\text { Red clover* (Trifolium pratense) }\end{array}$ & $\begin{array}{l}30-100 \\
15-25 \\
50-70 \\
\text { Trace } \\
\text { Trace }\end{array}$ & $\begin{array}{l}\text { Coumestans } \\
\text { Iso-flavones }\end{array}$ \\
\hline $\begin{array}{l}\text { Herbs } \\
\text { Chicory* (Cichorium intybus) } \\
\text { Sheep's burnet (Sanguisorba minor) } \\
\text { Plantain (Plantago lanceolata) }\end{array}$ & $\begin{array}{c}4-5 \\
3-4 \\
12-16\end{array}$ & $\begin{array}{l}\text { Sesquiterpene lactones (3.6) } \\
\text { Iridoid glycosides }\end{array}$ \\
\hline $\begin{array}{l}\text { Trees \& shrubs } \\
\text { Tree willow* (Salix matsudana x alba) } \\
\text { Osier willow* (Salix viminalis) } \\
\text { Kinuyanagi willow (S. kinuyanagi) } \\
\text { Dorycnium rectum (leaf) } \\
\text { Veronese poplar (Populus deltoids x nigra) }\end{array}$ & $\begin{array}{c}29 \\
66 \\
274 \\
200 \\
10\end{array}$ & $\begin{array}{l}\text { Phenolic glycosides } \\
\text { Phenolic glycosides } \\
\text { Phenolic glycosides } \\
\text { Phenolic glycosides }\end{array}$ \\
\hline
\end{tabular}

*Evaluated for deer feeding 
also appear to influence astringency (and hence feed intake) and the effectiveness of $\mathrm{CT}$ in precipitating protein in the rumen and increasing absorption of essential amino acids from the small intestine in sheep (Aerts et al. 1999; Barry \& McNabb 1999; Waghorn et al. 1994). Similar research has not been conducted in deer.

For sheep, CT concentrations above about $35-40 \mathrm{~g} / \mathrm{kg}$ DM (depending on plant species and type of CT) have resulted in reduced voluntary feed intake and reduced dry matter digestibility (Barry \& Duncan 1984; Barry \& McNabb 1999). Deer have evolved production of CTbinding proline-rich salivary proteins, as a means of counteracting plant defence mechanisms against herbivory and the anti-nutritional effects of high CT concentrations, probably due to their browsing habits and may tolerate higher concentrations or more astringent CT than sheep or cattle. No such proteins have been found in the saliva of domesticated sheep and cattle (Austin et al. 1989).

In NZ, sambar deer (Cervus unicolor) were shown to have a higher $\mathrm{CT}$ binding capacity of salivary proteins than red deer, corresponding to a greater dietary preference for browse species containing high concentrations of CT for sambar compared with red deer (Semiadi et al. 1995). These salivary proteins can have a high specificity for binding to CT only present in the normal diet (Hagerman \& Robbins 1993). However, the extent to which the production of these binding proteins might change, for example, as dietary CT concentrations or structure in the diet selected change with season is not known.

Barry \& McNabb (1999) suggest that the beneficial nutritional effects of dietary CT could only occur if the ruminant species concerned does not produce salivary CT-binding proteins. They also suggest that the opportunity for manipulation of nitrogen digestion in deer may be less than in sheep and cattle that don't produce CT-binding salivary proteins. This might be the case for forages with low $\mathrm{CT}$ concentrations, where most of the free CT is more likely to be bound up by salivary proteins. It is less likely for plant species with medium to high CT concentrations, when the concentration of $\mathrm{CT}$ in the diet exceeds the capacity of the salivary proteins for binding. This relationship may also vary according to the CTbinding capacity of the saliva produced by the deer species concerned, with sambar deer likely to need a diet higher in CT than red deer for nutritional benefits of CT to be seen. Also, given the specificity of CT-protein bonds, not all $\mathrm{CT}$ present in forages are likely to be bound to the same extent by salivary proteins. Therefore it is clear that the effect of CT upon the digestion and absorption of protein needs to be determined for deer fed forage diets. The significance of salivary binding of dietary $\mathrm{CT}$ on rumen degradation of protein and absorption in the small intestine also needs to be deter mined in deer.

The ability of CT in forage legumes to bind to soluble protein in the rumen reduces the incidence of frothy bloat, an important role of CT in diets of sheep and cattle. However, the high rumen outflow rate of liquid in deer (Domingue et al. 1991) means deer appear not to be susceptible to bloat.

Recent research showed feeding forages containing CT reduced methane emissions from dairy cows without compromising milk solids production (Woodward et al. 2002) and reduced methane production by sheep (Waghorn et al. 2002). Therefore another potential, unexplored role of CT-containing forages in sustainable deer production may be to reduce methane emissions.

\section{The role of alternative forage and browse species in deer production systems}

Research into forages for deer has centred on species with high nutritive value that produce more dry matter during the late spring, summer and autumn periods. This coincides with peak nutrient demand for lactation which is after peak pasture production in most environments. Deer production from perennial ryegrass-based swards is limited during late spring to autumn, due to slow growth in dry conditions and/or lower nutritive value (Barry \& Wilson 1994).

Most alternative forages evaluated for deer coincidentally contain significant levels of secondary compounds. Condensed tannin levels in some plants fed successfully to deer (e.g. sulla 84 g/kg DM CT, Hoskin et al. 1999b) can be deleterious to other ruminant livestock (Barry \& McNabb 1999). Grasslands Puna chicory has received most attention, but, red clover, birdsfoot trefoil and sulla have increased growth of young deer in comparison with that on PRG/WC pasture (Adu et al. 1998; Hoskin et al. 1999a,b; 2000; Kusmartono et al. 1996; Min et al. 1997; Niezen et al. 1993; Semiadi et al. 1993; Soetrisno et al. 1994). Their increased feeding value is largely attributed to increased voluntary feed intake and digestibility (Barry et al. 1998a).

Red deer prefer legumes (many containing CT) and chicory (containing CT and lactones) over PRG/WC pastures (Hunt \& Hay 1990; Scott 1989). Sambar deer prefer browse species such as willow (Semiadi et al. 1995). Red deer are classified as intermediate feeders, adapting well to browse and to forage grazing (Kay \& Staines 1981; Hoffman 1985). Fallow deer (Dama dama) are classified as intermediate feeders tending to bulk feeders, with grasses the predominant food source. They appear to be more selective grazers than red deer (Putman 1986; Kerridge \& Bullock 1991).

Genotype $\mathrm{x}$ nutrition interactions have been shown with different forage diets, with growth of young $1 / 4$ wapiti (Cervus elaphus canadensis): 3/4 red deer 
exceeding growth of pure red deer to a greater extent whilst grazing chicory compared with PRG/WC pasture (Kusmartono et al. 1996). The increased nutrient supply from chicory allowed the greater growth potential of the crossbred deer to be expressed. Therefore, when evaluating different plant species, it is important to consider the species of deer, their foraging habits and preferences, and the likely magnitude of response.

A significant deer health advantage contributing to sustainability of the system may be through higher essential trace elements in alternative forages. Chicory contains a higher concentration of most minerals than PRG/WC pasture (Barry et al. 2001). After autumn grazing of Grasslands Puna chicory, deer liver copper and vitamin B12, and blood selenium concentrations were significantly higher than those grazing conventional pasture (Barry et al. 2001; Wilson \& Grace 2002; Wilson unpublished). In addition, after winter when all deer were combined on pasture, despite no significant difference in mean liver copper levels of deer having grazed either chicory or pasture during autumn, significantly fewer deer having grazed chicory in autumn were at risk of copper deficiency (Grace et al. 2003). This aspect of forages and deer health is currently under further investigation. Studies to date highlight the largely unexplored potential of natural dietary components in meeting deer health requirements in a sustainable manner, using reduced or zero chemical inputs. The added benefit of reducing trace element supplementation also contributes to the cost-effectiveness of alternative plant species.

\section{Feeding value of forage legumes and herbs containing secondary plant compounds for farmed deer}

Other than studies of diet selection of red (Hunt \& Hay 1990; Scott 1989) and red versus sambar deer (Semiadi et al. 1995), little research has been conducted into the feeding value of forages or browse containing CT, or significant quantities of other known beneficial secondary compounds, specifically for NZ farmed deer. Furthermore, most research has taken place on a single property at Massey University, Palmerston North. Grasslands Puna chicory has been evaluated in a number of trials over several years, but red clover, birdsfoot

Table 2 Feeding value (indicated by seasonal liveweight gains, carcass weights and proportion of stags reaching $50 \mathrm{~kg}$ carcass weight at 12 months of age) of forage species for red deer determined from studies conducted at Massey University, Palmerston North (Barry et al. 1998b).

\begin{tabular}{|c|c|c|c|c|}
\hline $\begin{array}{c}\text { Perennial } \\
\text { Ryegrass/White } \\
\text { Clover Pasture } \\
10 \mathrm{~cm} \text { (9 studies) }\end{array}$ & $\begin{array}{l}\text { Chicory } \\
\text { (5 studies) }\end{array}$ & $\begin{array}{l}\text { Red Clover } \\
\text { (4 studies) }\end{array}$ & $\begin{array}{c}\text { Sulla } \\
\text { (1 study) }\end{array}$ & $\begin{array}{l}\text { Birdsfoot Trefoil } \\
\text { (2 studies) }\end{array}$ \\
\hline \multicolumn{5}{|c|}{ Growth of stag and hind calves from birth to weaning in late February $(\mathrm{g} / \mathrm{d})^{*}$} \\
\hline $\begin{array}{l}333 \\
331 \\
351 \\
399 \\
\end{array}$ & $\begin{array}{l}385(16) \\
404(16)\end{array}$ & $\begin{array}{l}433(30) \\
410(24)\end{array}$ & & $485(22)$ \\
\hline \multicolumn{5}{|c|}{ Growth of stags during autumn $(\mathrm{g} / \mathrm{d}) *$} \\
\hline $\begin{array}{l}178 \\
152 \\
176 \\
192 \\
207 \\
224 \\
\end{array}$ & $\begin{array}{l}246(38) \\
235(55) \\
154(-45)\end{array}$ & $\begin{array}{l}263(37) \\
237(14)\end{array}$ & $315(41)$ & $248(41)$ \\
\hline \multicolumn{5}{|c|}{ Growth of stags during spring $(\mathrm{g} / \mathrm{d})^{*}$} \\
\hline $\begin{array}{l}260 \\
285 \\
292 \\
341 \\
281 \\
289 \\
\end{array}$ & $\begin{array}{l}255(-2) \\
335(18)\end{array}$ & $\begin{array}{c}354(4) \\
346(23)\end{array}$ & $333(15)$ & $279(-5)$ \\
\hline \multicolumn{5}{|c|}{ Mean carcass weight of stags at 12 months $(\mathrm{kg})^{*}$} \\
\hline 53.8 & $56.4(5)$ & $59.6(11)$ & $63.1(17)$ & \\
\hline \multicolumn{5}{|c|}{ Mean $\%$ (range) of stags reaching $50 \mathrm{~kg}$ carcass at 12 months } \\
\hline $78(25-100)$ & $87(80-100)$ & 100 & 100 & \\
\hline
\end{tabular}

* Values in brackets are \% increases compared with grazing perennial ryegrass / white clover pasture. 
trefoil and sulla have been evaluated in 1-2 grazing seasons. A summary of the relative feeding value of forages containing secondary compounds evaluated for deer on the Massey University Deer Research Unit is presented in Table 2. It is not known what the contribution of the secondary compound per seis to the feeding value observed.

\section{Secondary plant compounds and internal parasitism in deer}

A range of known plant secondary compounds are present in plant species currently fed, or suitable for feeding to, farmed deer in NZ. In addition to knowing little about the majority of the known compounds, other than generalised antioxidant (Duke 1992), anti-bacterial and -fungal roles (Barry \& Blaney 1987), there are many compounds as yet unidentified. Internal parasites, particularly lungworm and abomasal nematodes, are significant contributors to production loss and risk of mortality in young farmed deer in NZ (Charleston 2001). A summary of work with forages containing CT and sesquiterpene lactones is presented here.

There are direct and indirect mechanisms by which forages containing secondary compounds may potentially reduce infection or ameliorate internal parasitism in ruminants. Plant chemicals may have direct inhibitory effects by binding to the parasites themselves in the digestive tract or faeces of the animal. The indirect effects of CT improving protein status of the host could increase the animal's tolerance of worm burdens. Further, plant morphology and sward structure may also influence the free-living stages of the parasites. The relative contribution of direct and indirect mechanisms has not been investigated.

Effects of grazing and feeding forages containing secondary compounds on internal parasitism

Most forage evaluations for grazing deer have employed routine 3 or 4-weekly anthelmintic treatment to eliminate the potentially confounding effect of internal parasites. When anthelmintic was given in response to predetermined levels of faecal egg or larvae counts or clinical signs were observed (trigger treatment), weaner deer grazing chicory did not require treatment during autumn, whereas clinical signs of lungworm, reduced voluntary feed intake and liveweight gains were observed in pasturegrazed weaners (Table 3; Hoskin et al. 1999a). This work is being repeated, with treatment criteria based on individual animal, rather than the group basis employed previously. A sub-sample of weaners were slaughtered for nematode counts at the end of the autumn grazing season in late May 2002, and preliminary results are presented in Table 4 . This confirmed that grazing chicory in autumn negates the reductions in weaner liveweight gain attributable to sub-clinical parasitism. It prevented clinical parasitism seen in untreated pasture-grazed weaners. Mean adult lungworm numbers in pasturegrazed weaners in late May were twice that of chicorygrazed weaners.

Indoor study of weaner deer artificially infected with lungworm and gastrointestinal parasites and fed either fresh harvested lucerne (negligible or trace CT), birdsfoot trefoil (19 g/kg DM CT) or sulla (35 g/kgDM CT) (Table 5) showed a negative linear relationship between dietary $\mathrm{CT}$ concentration and abomasal nematode numbers (Hoskin et al. 2000; Equation 1).

Table 3 Voluntary food intake (VFI), liveweight gain (LWG) and carcass weight of weaner deer grazing perennial ryegrass/white clover pasture and Grasslands Puna chicory and treated 3-weekly with anthelmintic* or treated on a group basis of production loss of clinical signs of parasitism (Hoskin et al. 1999).

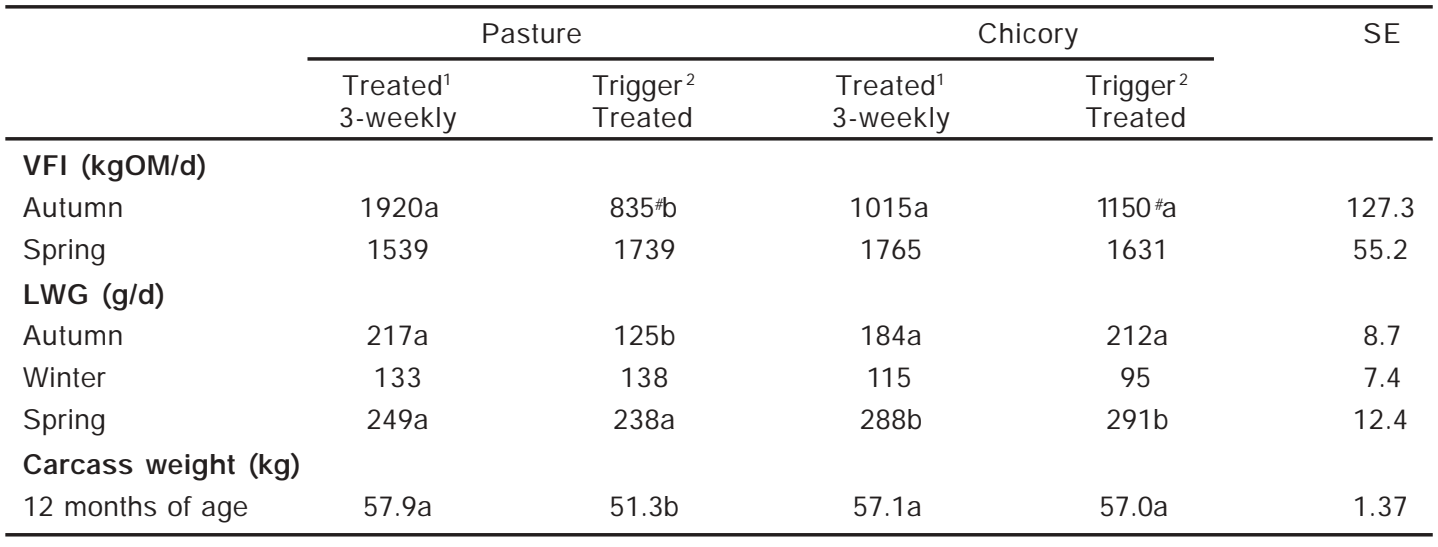

*Oral ivermectin was the anthelmintic used.

a, b: different letters denote significant differences $(P<0.05)$ within rows.

\#FI was measured prior to anthelmintic treatment being given to these groups.

1 Anthelmintic treated at 3 weekly intervals.

2 Anthelmintic withdrawn until trigger criteria were reached. 
Table 4 Preliminary data (not statistically validated) on the proportion of deer requiring anthelmintic treatment, average liveweight gain and number of adult lungworm recovered from weaner deer grazing perennial ryegrass/ white clover pasture or Grasslands Puna chicory during the autumn and either treated 4weekly with anthelmintic* or individually treated on the basis of production loss or clinical signs of parasitism (trigger-treated) (Hoskin et al. 2002 unpublished).

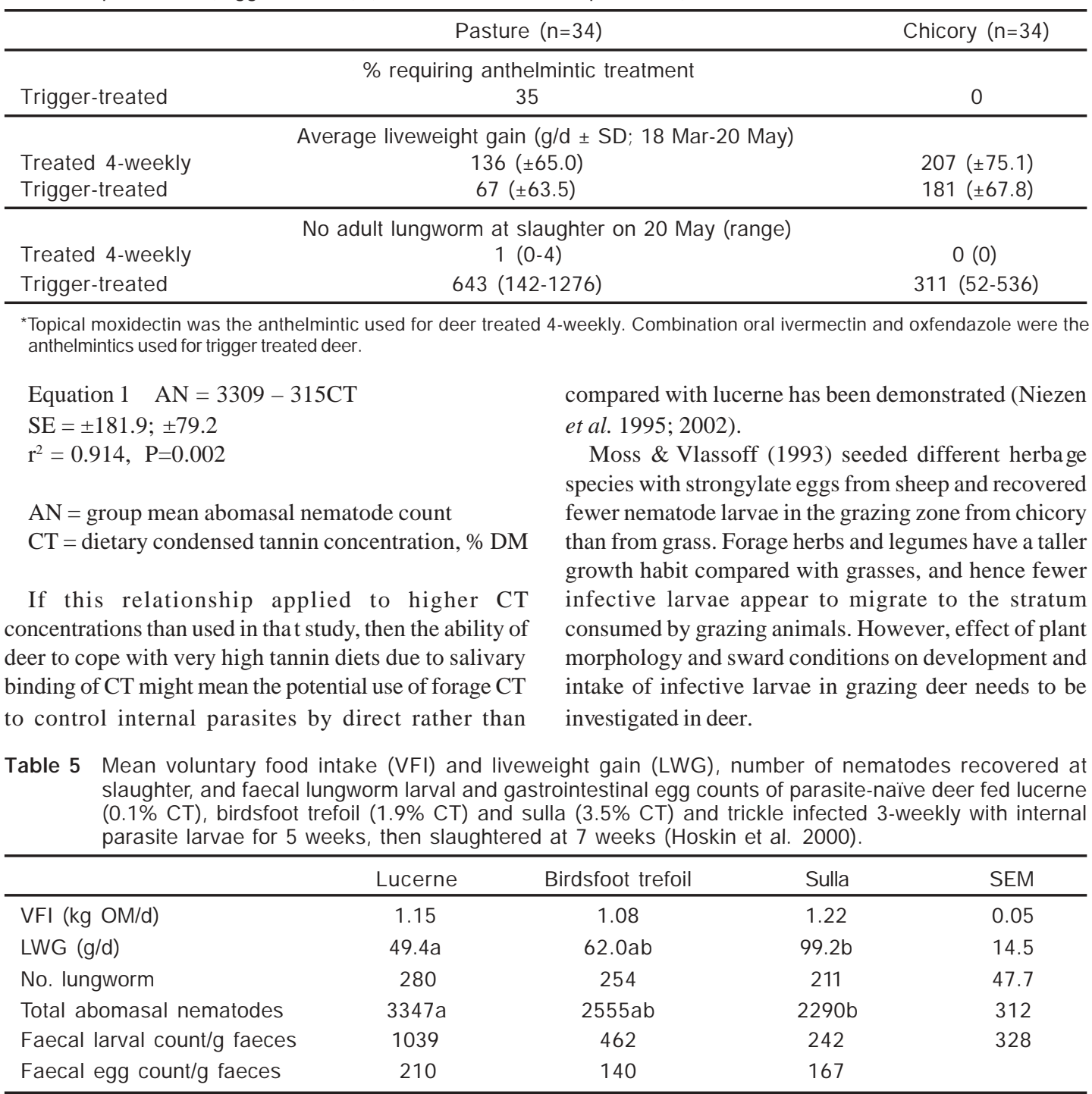

a, b: different letters denote significant differences $(P<0.05)$

nutritional effects in deer may be much greater than in other ruminants.

One mechanism by which CT may enhance the tolerance of deer to internal parasitism by improving amino acid supply to the small intestine (Coop \& Kyriazakis 1999). This could counteract protein losses caused by gut parasitism (Kimambo et al. 1988) that lead to reduced nitrogen retention (Bown et al. 1991) and also better meet the amino acid demands of the immune system. Increased resilience and immunogenic responses of sheep to internal parasitism whilst fed sulla

\section{Research into direct anthelmintic effects of secondary compounds}

Quebracho extract (Schinopsis sp.; containing CT) fed to sheep directly inhibited gastrointestinal parasites (Athanasiadou et al. 2001). CT extracted from lotus major, birdsfoot trefoil, sulla and sainfoin also showed direct inhibitory effects on the developmental first (L1) and infective third (L3) stages of deer lungworm (Dictyocaulus sp.) and the infective third (L3) stage of mixed species of deer gastrointestinal nematode larvae cultured from deer faeces (Molan et al. 2000b). Relative 
ranking of apparent anthelmintic activity of CT extracted from the forage legumes against all larvae was sainfoin $>$ lotus major > sulla > birdsfoot trefoil. To the authors' knowledge, sainfoin and lotus major have never been evaluated with grazing deer, probably due to agronomic limitations, but this result suggests their use as specialist feed supplements for deer parasite control should be evaluated.

The effects of CT extracted from seven plant species on egg hatching and larval development of Trichostrongylus colubriformis from sheep, also found in deer, was determined in-vitro (Molan et al. 2002). The CT from dock (Rumex obtusifolius) had the greatest inhibitory effect on egg development, followed by CT from Dorycnium rectum, sainfoin, Dorycnium pentaphylum, lotus major, sulla and birdsfoot trefoil. However deer tend to select against eating dock (S.Hoskin, personal observation).

There was no difference in the hatching of eggs from faeces of deer grazing chicory compared with perennial ryegrass-based pasture (Schreurs et al. 2002), but in vitro research using sesquitemene lactones extracted from chicory has shown similar inhibitory properties against deer parasite larvae to CT (Molan et al. 2000a). Schreurs et al. (2002) showed that faeces, rumen and abomasal fluid of deer grazing chicory contained compounds that inhibited the motility of deer L1 lungworm larvae, while compounds from the same sources from deer grazing PRG/WC did not (Table 6). and have poor persistence, and would provide an option for including CT in diets of deer on properties with limited flat land for growing crops. Other unexplored options include the use of native species such as broadleaf (Griselinia sp.) and mirror plant (Coprosma sp.) which are highly suitable for shelter and trimming and may contain desirable secondary compounds. They are highly preferred by wild red and fallow deer in NZ (Nugent 1990; Nugent et al. 2001).

However, caution must be advised as to the likely success of mixing dietary CT-containing and non-CT containing plants in a sward or harvested diet, with respect to improving protein supply to the small intestine. It is the free (rather than fibre- or protein-bound) fractions of CT that are most available for binding to dietary or rumen microbial proteins. These free CT react preferentially with proteins originating from the CT-containing temperate forages, rather than with proteins from other plants present in a mixed diet (Beever \& Siddons 1986; Barry \& McNabb 1999). It appears that beneficial effects of forage mixing would be more likely if the CT content is very high and the protein content relatively low in the CT-containing supplement, allowing release of free CT to bind with proteins from the basal non CT-containing diet. This is likely to occur with legume shrubs like $D$. rectum, but may not occur if low CT-containing willows like osier willow (see below) are used. These nutritionrelated processes may be further complicated by binding of free $\mathrm{CT}$ in the supplement by deer salivary proteins.

Table 6 The effect of source of faeces (chicory or pasture), source of fluid (chicory or pasture) and type of fluid (rumen or abomasal) upon the viability of deer L1 lungworm larvae as measured in vitro by the Larval Migration Inhibition Assay (Schreurs et al. 2002).

\begin{tabular}{lccc}
\hline $\begin{array}{l}\text { Forage type deer grazed on to obtain: } \\
\text { Faeces (larvae) }\end{array}$ & Fluid & $\begin{array}{c}\text { \% larvae not passing through sieves } \\
\text { Rumen Fluid }\end{array}$ & Abomasal Fluid \\
\hline Pasture & Pasture & $28 \mathrm{a}$ & $21 \mathrm{a}$ \\
Pasture & Chicory & $40 \mathrm{~b}$ & $30 \mathrm{~b}$ \\
Chicory & Pasture & $44 \mathrm{~b}$ & $39 \mathrm{~b}$ \\
Chicory & Chicory & $49 \mathrm{~b}$ & $40 \mathrm{~b}$ \\
SEM & & 2.0 & 2.0 \\
\hline
\end{tabular}

$\mathrm{a}, \mathrm{b}$ : different letters denote significant differences between columns $(\mathrm{P}<0.01)$

The potential of browse feeding for farmed deer The presence of tannin-binding proteins in deer saliva means there may be greater potential to use browse species containing high CT concentrations for farmed deer than other domestic ruminants.

Evaluation of poplars (Populus spp) and willows (Salix spp) for supplementary feeding of cattle (Moore et al. 2002) and sheep (McWilliamet al. 2002 \& unpublished) during drought conditions has highlighted a nutritional use for plants used as shelter on farms. This might provide an alternative to stands of specialist CT containing legumes, such as sulla, which are difficult to establish
Investigation into the chemistry of tannin-plant protein and tannin-salivary protein bonds is required when mixed versus single species diets are fed.

Limited data exists on feeding of browse or tree species to farmed deer. McCa be \& Barry (1988) fed tree willow (Salix matsudana x alba 'Wairakei'; 29 g/kgDM CT) and osier willow (Salix viminalis 'Gigantea'; $66 \mathrm{~g} / \mathrm{kgDM}$ CT) as a sole diet to sheep, goats and red deer. Osier willow had a lower nutritive value for sheep and goats than tree willow based on voluntary feed intake, apparent DM digestibility and CT content. Red deer consumed more osier willow than tree willow despite the higher 
CT concentration of osier willow, which contradicts the data from sheep and goats (Table 7). This is yet another indication that red deer are able to cope better with higher CT concentrations than sheep and goats.

Current research (Hoskin \& Waghorn unpublished) is evaluating supplementary feeding of $D$. rectum to red deer, with deer readily accepting a diet consisting of $20 \%$ D.rectum (200 g/kg DM CT) and 80\% PRG/WC

Table 7 Voluntary feed intake and CT concentration of tree (Salix matsudana $x$ alba) and osier (Salix viminalis) willow by sheep, goats and red deer, expressed relative to that of lucerne hay (McCabe \& Barry 1988).

\begin{tabular}{lcc}
\hline & Tree willow & Osier willow \\
\hline CT (g/kg DM) & 29 & 66 \\
Voluntary feed intake relative to lucerne hay & \\
Sheep & 0.71 & 0.6 \\
Goats & 1.34 & 1.18 \\
Deer & 0.85 & 1.00 \\
\hline
\end{tabular}

alternative forage species.

4. The feeding value and benefits to deer health of feeding lotus major, sainfoin, plantain and other potential new forages containing secondary compounds need to be determined.

5. The secondary compounds are present in poplar, willow and NZ native tree and shrub species potentially suitable for shelter / browse on deer farms needs to be measured and their effects upon deer health and productivity determined. If shown to be beneficial, their integration into deer farming systems would require evaluation.

Confirmation and validation of research centre findings in commercial farming environments, and their application to deer production systems are essential prerequisites to adoption by deer producers. pasture, giving a dietary average CT content of $40 \mathrm{~g} / \mathrm{kg}$ DM. From an agronomic perspective, Oppong et al. (2001) found osier (S. matsudana x alba) and kinuyanagi (S.kinuyanagi) willows to have greater potential as browse species than $D$. rectum due to their higher yield. However, Douglas \& Foote (1994) found D. rectum (20t DM/ha) could produce yields exceeding that of lucerne (14t DM/ha).

\section{Conclusions and future challenges}

Research into effects of forages containing CT and sesquiterpene lactones, on internal parasites has highlighted an important potential role in sustainable deer production systems. Improved health and productivity, and reduced chemical input provide more ecologically sustainable and consumer-friendly deer management practices.

However, further research is needed to evaluate the following:

1. The effect of CT upon the digestion of protein and absorption of amino acids in deer fed forage and browse diets.

2. The saliv ary protein CT-binding capacity in farmed deer fed forage diets needs to be determined, including its variability with diet and whether this phenomenon is likely to limit the opportunities for manipulation of nitrogen digestion by $\mathrm{CT}$ or anthelmintic effects of CT, and whether it is likely to result in deer consuming higher CT-containing plants.

3. The relative contributions of secondary compound mediated direct anthelmintic effects, compared with indirect nutritional, plant morphological and sward structure effects on reduction of production losses attributable to internal parasitism in deer fed

\section{REFERENCES}

Adu, E.K.; Barry, T.N.; Wilson, P.R.; Kemp, P.D. 1998. Evaluation of Lotus corniculatus for increasing preweaning growth of red and hybrid deer. Journal of Agricultural Science, Cambridge 131: 197-204.

Aerts, R.J.; McNabb, W.C.; Molan, A.L.; Brand, A.; Peter s, J.S .; Barry, T.N. 1999. Condensed tannins from Lotus corniculatus and Lotus pedunculatus effect the degradation of ribulose 1,5-bisphosphate carboxylase (Rubisco) protein in the rumen differently. Joumal of the Science of Food and Agriculture 79: 79-85.

Asquith, T.N.; Butler, L.G. 1986. Interactions of condensed tannins with selected proteins. Phytochemistry 25: 1591-1593.

Athanasiadou, S.; Kyriazakis, I.; Jackson, F.; Coop, R.L. 2001. Direct anthelmintic effects of condensed tannins towards different gastrointestinal nematodes of sheep: in vitro and in vivo studies. Veterinary Parasitology 99: 205-219.

Austin, P.J.; Suchar, L.A.; Robbins, C.T.; Hagerman, A.E. 1989. Tannin-binding proteins in the saliva of deer and their absence in saliva of sheep and cattle. Journal of Chemical Ecology 15: 1335-1347.

Barry, T.N.; Duncan, S.J. 1984. The role of condensed tannins in the nutritional value of Lotus pedunculatus for sheep. 1. Voluntary intake. British Journal of Nutrition 51: 485-491.

Barry, T.N.; Blaney, B.J. 1987. Secondary compounds of forages. pp. 91-119. In: Nutrition of Herbivores. Eds. Hacker, J.B.; Ternouth, J.H. Academic Press, Australia.

Barry, T.N.; McNabb, W.C. 1999. The implications of condensed tannins on the nutritive value of temperate forages fed to ruminants. British Journal of Nutrition 
81: 263-272.

Barry, T.N.; Wilson, P.R. 1994. Review: Venison production from farmed deer. Joumal of Agricultural Science, Cambridge 123: 159-165.

Barry, T.N.; Wilson, P.R.; Semiadi, G. 1998a. Growth, voluntary feed intake and digestion in farmed temperate and tropical deer. Acta Veterinaria Hungarica 46:369380 .

Barry, T.N.; Wilson, P.R.; Kemp, P.D. 1998b. Management of grazed pastures and forages for optimum deer production. Proceedings of the $2^{\text {nd }}$ World Deer Farming Congress, Limerick, Ireland 141-160.

Bary, T.N.; Molan, A.L.; Wilson, P.R.; Lopez-Villalobos, N.; Schreurs, N.M.; Duncan, J.A. 2001. Chicory as an alternative forage for deer health. Proceedings of a Deer Course for Veterinarians, Deer Branch of the New Zealand Veterinarians Association 18: 122-127.

Barry, T.N.; Hoskin, S.O.; Wilson, P.R. 2002. Novel forages from growth and health in farmed deer. New Zealand Veterinary Journal (In Press).

Beever, D.E.; Siddons, R.C. 1986. Digestion and metabolism in the grazing ruminant. pp. 479-497. In: Control of Digestion and Metabolism in Ruminants. Eds. Milligan, L.P.; Grovum, W.L. and Dobson, A. Englewood Cliffs, NJ: Prentice Hall.

Bermingham, E.N.; Hutchinson, K.J.; Revell, D.K.; Brookes, I.M.; McNabb, W.C. 2001. The effects of condensed tannins in sainfoin and sulla on the digestion of amino acids in sheep. Proceedings of the New Zealand Society of Animal Production 61: 116-119.

Bown, M.D.; Poppi, D.P.; Sykes, A.R. 1991. The effect of post-ruminal infusion of protein or energy on the pathophysiology of Trichostrongylus colubriformis infection and body composition in lambs. Australian Journal of Agricultural Research 42: 253-267.

Charleston, W.A.G. 2001. Review of deer anthelmintics. Proceedings of a Deer Course for Veterinarians, Deer Branch of the New Zealand Veterinarians Association 18: 144-152.

Coop, R.L.; Kyriazakis, I. 1999. Nutrition - parasite interactions. Veterinary Parasitology 84:187-204.

Domingue, B.M.F.; Dellow, D.W.; Wilson, P.R.; Barry, T.N. 1991. Comparative digestion in deer, goats and sheep. New Zealand Journal of Agricultural Research 34: $45-53$.

Douglas, G.B.; Foote, A.G. 1994. Establishment of perennial species useful for soil conservation. Proceedings of the New Zealand Grassland Association 45: 239-242.

Duke, J.A. 1992. Handbook of Biologically Active Phytoc hemicals and their Activities. CRC Press, Boca Raton, London, Tokyo.

Grace, N.D.; Wilson, P.R.; Nicol. A. 2003. The copper nutrition of grazing deer. The nutrition and management of deer on grazing systems. Grassland Research and Practice Series 9: 113-120.

Hagerman, A.E.; Robbins, C.T. 1993. Specificity of tannin-binding salivary proteins relative to diet selection in mammals. Canadian Journal of Zoology 71: 628-633.

Hanley, T.A. 1997. A nutritional view of understanding and complexity in the problem of diet selection by deer (Cervidae). Oikos 79: 209-218.

Hoffman, R.R. 1985. Digestive physiology of the deertheir morphophysiological specialisation and adaptation. pp 393-407. In: Biology of Deer Production. Eds. Fennessy P.F.; Drew K.R. The Royal Society of New Zealand Bulletin 22.

Hoskin, S.O.; Barry, T.N.; Wilson, P.R.; Charleston, W.A.G.; Hodgson, J. 1999a. Effect of reducing anthelmintic input upon growth and faecal egg and larvae counts in young farmed deer grazing chicory and perennial ryegrass/ white clover pasture.Journal of Agricultural Science, Cambridge 132: 335-345.

Hoskin, S.O.; Bary, T.N.; Wilson, P.R.; Charleston, W.A.G.; Kemp, P.D. 1999b. Growth and carcass production of young farmed deer grazing sulla, chicory or perennial ryegrass/white clover pasture in New Zealand. New Zealand Journal of Agricultural Research 42: 83-92.

Hoskin, S.O.; Wilson, P.R.; Barry, T.N.; Charleston, W.A.G.; Waghorn, G.C. 2000. Effect of for age legumes containing condensed tannins on lungworm and gastrointestinal parasitism in young red deer. Research in Veterinary Science 68: 223-230.

Hunt, W.F.; Hay, R.J.M. 1990. A photographic technique for assessing the pasture species preference of grazing animals. Proceedings of the New Zealand Grassland Association 51: 191-196.

Kay, R.N.B.; Staines, B.W. 1981. The nutrition of the red deer (Cervus elaphus). Nutrition Abstracts and Reviews, Series B 51: 601-622.

Kerridge, F.J.; Bullock, D.J. 1991. Diet and dietary quality of red deer and fallow deer in late summer. Journal of Zoology, London 224: 333-337.

Kimambo, A.E.; MacRae, J.C.; Walker, A.; Watt, C.F.; Coop, R.L. 1988. The effect of prolonged subclinical infection with Trichostrongylus colubriformis on the performance and nitrogen metabolism of growing lambs. Veterinary Parasitology 28: 191-203.

Kusmartono; Barry, T.N.; Wilson, P.R.; Kemp, P.D.; Stafford, K.J. 1996. Effects of grazing chicory (Cichorium intybus) and perennial ryegrass (Lolium perenne)/white clover (Trifolium repens ) pasture upon the growth and voluntary feed intake of red and hybrid deer during lactation and post-weaning growth. Journal of Agricultural Science, Cambridge 127: 387 401 . 
Kusmartono. 1996. Nutritive value of chicory (Cichorium intybus) as a special purpose forage for deer production. $\mathrm{PhD}$ thesis, Massey University, New Zealand.

Loza, M.J. 2001. Sensitive issues for the deer industry. Proceedings of a Deer Cour se for Veterinarians, Deer Branch of the New Zealand Veterinarians Association 18: 73-78.

McCabe, S.M.; Barry, T.N. 1988. Nutritive value of willow (Salix sp.) for sheep, goats and deer. Journal of Agricultural Science, Cambridge 111: 1-9.

McWilliam, E.L.; Barry, T.N.; Kemp, P.D.; LopezVillalobos; Cameron, P.N. 2002. Responses to poplar supplementation in ewes grazing drought pasture during mating. Proceedings of the New Zealand Society of Animal Production 62: 174-176.

Min, B.R.; Barry, T.N.; Wilson, P.R.; Kemp, P.D. 1997. The effects of grazing chicory and birdsfoot trefoil on venison and velvet production by young red and hybrid deer. New Zealand Joumal of Agricultural Research 40: 335-347.

Min, B.R.; McNabb, W.C.; Barry, T.N.; Kemp, P.D.; Waghorn, G.C.; McDonald, M.F. 1999. The effect of condensed tannins in Lotus corniculatus upon reproductive efficiency and wool production in sheep during late summer and autumn. Journal of Agricultural Science, Cambridge 132: 323-334.

Min, B.R.; Fernandez, J.M.; Barry, T.N.; McNabb, W.C.; Kemp, P.D. 2001. The effect of condensed tannins in Lotus corniculatus upon reproductive efficiency and wool production in ewes during autumn. Animal Feed Science and Technology 92:185-202.

Molan, A.L.; Duncan, A.; Barry, T.N.; McNabb, W.C. 2000a. Effect of condensed tannins and sesquiterpene lactones extracted from chicory on the viability of deer lungwom larvae. Proceedings of the New Zealand Society of Animal Production 60: 26-29.

Molan, A.L.; Hoskin, S.O.; Barry, T.N.; McNabb, W.C. 2000b. Effect of condensed tannins extracted from four forages on the viability of the larvae of deer lungworm and gastrointestinal nematodes. The Veterinary Record 147: 44-48.

Molan, A.L.; Waghorn, G.C.; McNabb, W.C. 2002. Effect of condensed tannins on egg hatching and larval development of Trichostrongylus colubriformis in vitro. The Veterinary Record 150: 65-69.

Moore, G.H.; Littlejohn, R.P.; Cowie, G.M. 1988. Liveweights, growth rates and mortality of farmed red deer at Invermay. New Zealand Journal of Agricultural Research 31: 293-300.

Moore, K.M.; Barry, T.N.; Cameron, P.N.; LopezVillalobos, N.; Cameron, D.J. 2002. Willow (Salix sp.) as a supplement for grazing cattle under drought conditions. Animal Feed Science and Technology (In
Press).

Moorehead, A.J.E.; Judson, H.G.; Stewart, A.V. 2002. Liveweight gain of lambs grazing 'Ceres Tonic' plantain (Plantago lanceolata) or perennial rygrass (Lolium perenne). Proceedings of the New Zealand Society of Animal Production 62: 171-173.

Moss, R.A.; Vlassoff, A. 1993. Effect of herbage species on gastrointestinal roundworm populations and their distribution. New Zealand Journal of Agricultural Research 36: 371-375.

Niezen, J.H.; Barry, T.N.; Hodgson, J.; Wilson, P.R. Ataja, A.M.; Parker, W.J.; Holmes, C.W. 1993. Growth responses in red deer calves and hinds grazing red clover, chicory and perennial ryegrass/white clover swards during lactation. Journal of Agricultural Science, Cambridge 121: 255-263.

Niezen, J.H.; Waghorn, T.S.; Charleston, W.A.G.; Waghorn, G.C. 1995. Growth and gastrointestinal nematode parasitism in lambs grazing either lucerne or sulla which contains condensed tannins. Journal of Agricultural Science, Cambridge 125: 281-289.

Niezen, J.H.; Waghorn, T.S.; Char leston, W.A.G. 1998. Establishment and fecundity of Ostertagia circumcincta and Trichostrongylus colubriformisin lambs fed lotus (Lotus pedunculatus) or perennial ryegrass (Lolium perenne). Veterinary Parasitology 78: 13-21.

Niezen, J.H.; Charleston, W.A.G.; Robertson, H.A.; Shelton,D.; Waghorn, G.C.; Green, R. 2002. The effect of feeding sulla (Hedysarum coronarium) or lucerne (Medicago sativa) on lamb parasite burdens and development of immunity to gastrointestinal nematodes. Veterinary Parasitology 105: 229-245.

Nugent, G. 1990. Forage availability and the diet of fallow deer (Dama dama) in the Blue Mountains, Otago. New Zealand Journal of Ecology 13: 83-95.

Nugent, G, Fraser, K.W.; Asher, G.W.; Tustin, K.G. 2001. Advances in New Zealand mammalogy 19902000: Deer. Journal of the Royal Society of New Zealand 31: 263-298.

Oppong, S.K.; Kemp, P.D.; Douglas, G.B .; Foote, A.G. 2001. Browse yield and nutritive value of two Salix species and Dorycnium rectum in New Zealand. Agroforestry Systems 51: 11-21.

Putman, R.J. 1986. Grazing in temperate ecosystems: large herbivores and the ecology of the New Forest. London: Croom Helm.

Rosenthal, G.E.; Janzen, D.H. (Eds.) 1979. Herbivores: their interaction with secondary plant metabolites. Academic Press, New York.

Schreurs, N.M.; Molan, A.L.; Lopez-Villalobos, N.; Barry, T.N.; McNabb, W.C. 2002. Effect of grazing undrenched weaner deer on chicory or perennial ryegrass/ white clover pasture on gastrointestinal nematode and lungwom viability. Proceedings of the 
New Zealand Society of Animal Production 62: 143144.

Scott, I. 1989. Pasture preferences of deer. Proceedings of a Deer Course for Veterinarians, Deer Branch of the New Zealand Veterinarians Association 6: 176180.

Semiadi, G.; Barry, T.N.; Wilson, P.R.; Hodgson, J.; Purchas, R.W. 1993. Growth and venison production from red deer (Cervus elaphus) grazing red clover (Trifolium pratense) or perennial ryegrass (Lolium perenne) white clover (Trifolium repens) pasture. Journal of Agricultural Science, Cambridge $121: 265$ 271.

Semiadi, G.; Barry, T.N.; Muir, P.D.; Hodgson, J. 1995. Dietary preferences of sambar (Cervus unicolour) and red deer (Cervus elaphus) offered browse, forage legume and grass species. Journal of Agricultural Science, Cambridge 125: 99-107.

Soetrisno, E.; Barry, T.N.; Wilson, P.R.; Hodgson, J.; Purchas, R.W. 1994. Effects of grazing red clover (Trifolium pratense) or perennial ryegrass (Lolium perenne)/white clover (Trifolium repens) pastures upon growth and venison production from weaner red deer (Cervus elaphus). New Zealand Journal of Agricultural Research 37: 19-27.

Swain, A. 1979. In: Herbivores; Their Interaction with Secondary Plant Metabolites. pp. 657-682. Eds. Rosenthal G.A.; Janzen, D.H. Academic Press, London \& New York.

Terrill, T.H.; Waghorn, G.C.; Woolley, D.J.; McNabb, W.C.; Barry, T.N. 1994. Assay and digestion of ${ }^{14} \mathrm{C}-$ labelled condensed tannins in the gastrointestinal tract of sheep. British Journal of Nutrition 72: 467-477.

Waghorn, G.C.; Shelton, I.D.; McNabb, W.C.; McCutcheon, S.H. 1994. Effects of condensed tannins in Lotus pedunculatus on its nutritive value for sheep. 2. Nitrogenous aspects. Journal of Agricultural Science, Cambridge 123: 109-119.

Waghorn, G.C.; Tavendale, M.H.; Woodfield, D.R. 2002. Methanogenesis from forages fed to sheep. Proceedings of the New Zealand Grassland Association 64: 167-171.

Wang, Y.; Douglas, G. B.; Waghom, G. C.; Barry, T. N.; Foote, A. G. 1996a. Effect of condensed tannins in Lotus corniculatus upon lactation performance in ewes. Journal of Agricultural Science, Cambridge 126: 353362.

Wang, Y.; Douglas, G. B.; Waghom, G. C.; Bary, T. N.; Foote, A. G.; Purchas, R. W. 1996b. Effect of condensed tannins upon the performance of lambs grazing Lotus corniculatus and lucerne (Medicago sativa). Journal of Agricultural Science, Cambridge 126: 87-98.

Wilson, P.R.; Grace, N.D. 2002. Practical considerations for diagnosis and management of copper status of deer. Proceedings of the New Zealand Society of Animal Production 62: 315-318.

Wilson, P.R.; Barry, T.N.; Hoskin, S.O. 2002. The role of alternative pasture species for farmed game health and productivity: observations from red deer. pp.143152. In: Game Conservation and Sustainability: Biodiversity, Mana gement, Ecotourism, Traditional Medicine and Health. Proceedings of the $4^{\text {th }}$ Intemational Wildlife Ranching Symposium. Ed. Renecker L.A. TA.

Woodward, S.L.; Waghorn, G.C.; Lassey, K.R.; Laboyrie, P.G. 2002. Does feeding sulla (Hedysarum coronarium) reduce methane emissions from dairy cows? Proceedings of the New Zealand Society of Animal Production 62:227-230. 